\title{
TITLE:
}

\section{Occurrence of dentate granule cell LTP without proximal dendritic Ca2+ increase.(Abstract_要旨)}

\section{AUTHOR(S):}

Hashimoto, Kenji

\section{CITATION:}

Hashimoto, Kenji. Occurrence of dentate granule cell LTP without proximal dendritic Ca2+ increase.. 京都大学, 2004, 博士(医学)

ISSUE DATE:

2004-03-23

URL:

http://hdl.handle.net/2433/147498

RIGHT: 


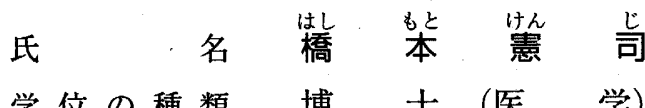

学位の種類博士 (医学)

学位記番号医博第 2720 号

学位授与の日付、平成 16 年 3 月 23 日

学位授与の要件 学 位 規 則第 4 条第 1 項該 当

研究科 - 専攻医学研究科脳統御医科学系専攻

学位論文題目 Occurrence of dentate granule cell LTP without proximal dendritic $\mathrm{Ca} 2+$ increase. に関する研究

(ラット海馬歯状回顆粒細胞における長期增強と細胞内カルシウムに関する研 究)

論文調查委員 教主授 ${ }^{\text {森 }}$ 治紀教授金子武嗣教授橋本信夫

論文内容の要旨

本論文はラット海馬歯状回の顆粒細胞における活動電位依存性細胞内カルシウム濃度上昇と貫通線維（perforant path)－顆粒細胞間シナプスにおける長期增強（LTP）との関連についてパッチクランプによるカルシウムイメージング及 びフィールドポテンシャルを用いて行われた研究に関するものである。

ほ乳類の中枢神経に扔けるほとんどのニューロンは活動電位を介して情報を記号化し伝達している。この電気的活動が二 ューロンのどこで発生し, どのように伝播するのかを知るということはニューロンの機能を理解する上できわめて重要な課 題である。

活動電位が軸索だけでなく樹状突起でも起こることは古くから知られているが, 近年の研究により錐体細胞・非錐体細胞 を問わず多くの神経細胞では細胞体から生じて樹状突起を近位部から遠位部に逆行性伝播する活動電位が存在し, 海馬や大 脳新皮質の錐体細胞ではこの逆行性伝播活動電位が樹状突起内で逆行性の細胞内カルシウム濃度上昇を起こしてLTPの誘 発に決定的に関与することが知られている。上記の錐体細胞と同様にLTPを起こしうる非錐体細胞のひとつとして海馬歯 状回顆粒細胞があり，その樹状突起内逆行性細胞内カルシウム濃度上昇とLTP 誘発との関連については未だ不明である。

ラットの脳スライスでパッチクランプを用いた実験にて歯状回顆粒細胞樹状突起近位部に生じる高頻度刺激 $(100 \mathrm{~Hz}$, $0.4 \mathrm{sec）}$ 誘発性カルシウム濃度上昇は，L型電位依存カルシウムチャンネルプロッカーであるニモジピン及び NMDA 受容 体拮抗薬である（士)-2-amino-5-phosphonopentanoic acid（DL-AP-5）のいずれの灌流漕内投与によっても著しく抑制さ れた。フィールドポテンシャルを用いた実験では貫通線維一顆粒細胞間シナプスにおいての高頻度刺激誘発性 LTPはDLAP-5 の灌流漕内投与によりブロックされたが, ニモジピンではブロックされなかった。ここで，もし貫通線維一顆粒細胞 間シナプスにおけるLTPがシャファー側枝ーCA1 間シナプスのLTPのように逆行性伝播性樹状突起活動電位に伴う樹状突 起内カルシウム濃度上昇の逆行性伝播が不可欠であると仮定するならば, ニモジピン存在下でのLTP誘導の際に樹状突起 近位部おいて十分なカルシウム上昇が観察されるはずであるが，実際は観察されなかった。これらのことより貫通線維一顆 粒細胞間シナプスにおけるLTPでは海馬・新皮質の錐体細胞とは異なり, 逆行性伝播性樹状突起活動電位に伴う樹状突起 内カルシウム濃度上昇の逆行性伝播に依存せずにLTPが誘発されうることが明らかとなった。

\section{論 文審 查 の結 果 の 要 旨}

近年の研究により多くの神経細胞では軸索小丘で生じて樹状突起を近位から遠位に逆行性伝播する活動電位が存在し, 海 馬 $\mathrm{CA} 1 \cdot$ 大脳新皮質の錐体細胞ではこの活動電位が樹状突起内で逆行性細胞内カルシウム濃度上昇を起こして長期增強誘 発に決定的に関与することが知られるようになった。上記錐体細胞と同様に長期増強を起こしうる細胞として海馬歯状回顆 粒細胞がある。本研究において, この非錐体細胞である顆粒細胞では錐体細胞とは異なる長期增強の制御が存在することが 証明された。 
ラット脳スライスでパッチクランプ法を用いたカルシウムイメージング実験にて歯状回顆粒細胞の樹状突起近位部に生じ る高頻度刺激誘発性カルシウム濃度上昇は，L型電位依存性カルシウムチャンネルブロッカーであるニモジピン及び NMDA 受容体拮抗薬であるDL-AP-5のいずれによっても著しく抑制された。フィールドポテンシャルを用いた実験では 高頻度刺激誘発性長期増強はDL-AP-5により阻害されたが，ニモジピンでは阻害されなかった。

これらより，歯状回顆粒細胞においては錐体細胞とは異なり，逆行性伝播性樹状突起活動電位に伴う逆行性樹状突起内力 ルシウム濃度上昇に依存せずに長期増強が誘発されうることが明らかとなった。

以上の研究は中枢神経における可塑性の制御とセカンドメッセンジャーとしての細胞内カルシウム濃度変化の解明に寄与 するところが大きい。

従って，本論文は博士（医学）の学位論文として洒値あるものと認める。

なお，本学位授与申請者は，平成16年 2 月 9 日実施の論文内容とそれに関連した試問を受け，合格と認められたものであ る。 